\title{
Synthesis, Molecular Modelling and Anticancer Activities of New Molecular Hybrids Containing 1,4-Naphthoquinone, 7-Chloroquinoline, 1,3,5-Triazine and Morpholine Cores as PI3K and AMPK Inhibitors in the Metastatic Melanoma Cells
}

\author{
Rodolfo G. Fiorot, ${ }^{\oplus *, a}$ Regina Westphal, ${ }^{b}$ Bárbara C. Lemos, ${ }^{b}$ Rodrigo A. Romagna, ${ }^{b}$ \\ Paola R. Gonçalves, ${ }^{c}$ Maruska R. N. Fernandes, ${ }^{d}$ Carmen V. Ferreira, ${ }^{d}$ Alex G. Taranto ${ }^{e}$ \\ and Sandro J. Greco ${ }^{\circledR} *, b$ \\ aInstituto Federal de Ciências, Educação e Tecnologia do Rio de Janeiro, \\ 21710-240 Rio de Janeiro-RJ, Brazil \\ ${ }^{b}$ Laboratório de Síntese Orgânica e Aplicada, Departamento de Química, \\ Universidade Federal do Espírito Santo, 29075-910 Vitória-ES, Brazil \\ 'Departamento de Ciências da Saúde, Centro Universitário Norte do Espírito Santo (CEUNES), \\ Universidade Federal do Espírito Santo, 29932-540 São Mateus-ES, Brazil \\ ${ }^{d}$ Departamento de Bioquímica e Biologia Tecidual, Instituto de Biologia, \\ Universidade Estadual de Campinas, 13083-970 Campinas-SP, Brazil \\ ${ }^{e}$ Laboratório de Química Farmacêutica, Universidade Federal de São João del Rei, \\ Campus Centro Oeste, 35501-296 Divinópolis-MG, Brazil
}

\begin{abstract}
Three molecular hybrids containing 1,4-naphthoquinones, 1,3,5-triazines, morpholine and 7-chloroquinoline, which have recognized contributions to the biological activity of many drugs, were synthesized in yields ranging from $43-84 \%$. All hybrids were obtained in three steps starting from readily available reactants: lawsone, cyanuric chloride, morpholine and 4,7-dichloroquinoline. A previous docking study was carried out to identify the binding energy and pharmacophore conformation of the promising anticancer compounds with PI3K $\gamma$ (phosphoinositide 3-kinase) and AMPK (5' AMP-activated protein kinase). The cancer activity in human metastatic melanoma cells (SKMEL-103) were performed, and the synthetized compounds presented half maximal inhibitory concentration $\left(\mathrm{IC}_{50}\right.$ ) values around $25 \mu \mathrm{M}$. The expressions of PI3K and AMPK were also determined using western blotting technique, and all molecular hybrids negatively modulated both targets.
\end{abstract}

Keywords: molecular hybridization, anticancer activity, 1,4-naphthoquinone, 1,3,5-triazine, 7-chloroquinoline

\section{Introduction}

Continuous studies are essential to understand the mechanisms of cancer evolution and to provide more efficient and selective ways to eradicate it. Cancer is one of the prominent causes of morbidity and mortality worldwide; it is the second leading cause of death globally, thus, development of new drugs more selective and potent is necessary. ${ }^{1}$

The polypharmacology is not a new concept and the approaches adopted for administering the two or more drugs together are varied. Taking two or more drugs

*e-mail: rodolfo.fiorot@ifrj.edu.br; grecosj@ outlook.com simultaneously, co-formulation of two or more active agents in a single tablet and development of hybrid molecular entities capable to modulate multiple targets are the three popular approaches for multidrug therapy. Hence, the present form of polypharmacology is gaining popularity in the form of hybrid molecules (multiple ligand approach). ${ }^{2}$

Molecular hybridization ( $\mathrm{MH}$ ) is a strategy of rational design of new prototypes, where the lead compound is produced through an adequate fusion of pharmacophoric sub-unities. MH is performed to achieve one of the following objectives: (i) synergism of pharmacological action, (ii) dual action therapy pharmacological or (iii) modulation of undesirable side effects. ${ }^{3}$ 
The synergistic action hybrid is obtained when pharmacophoric groups or whole drugs are covalently linked. Both should have the same pharmacological action, but should act on different biochemical targets. The final objective of the hybrid will be to increase a single pharmacological activity by different pathways. ${ }^{4}$

Recently, one of the most frequently used cancer treatment approaches is to inhibit enzymes involved in the signaling pathway. ${ }^{5,6}$ This is a more selective and efficient way to stop cancer development because cancerous cells have signaling pathways that are overexpressed compared to healthy ones. ${ }^{7,8} \mathrm{PI} 3 \mathrm{~K}$ (phosphoinositide 3-kinase) and AMPK (5' AMP-activated protein kinase) kinases, which are key players in autophagy, are highlighted as important targets of cancer chemotherapy once they are strongly associated to the cell reproduction. ${ }^{9-12}$ One example of a cancer cell line with those overexpressed kinases is the human metastatic melanoma (SKMEL), which is the most aggressive skin cancer form. Pharmacological studies reveal that $\mathrm{PI} 3 \mathrm{~K}^{13}$ and $\mathrm{AMPK}^{14}$ signaling cascades directly impact different phenotypes of melanomas in its initiation, progression, drug resistance and invasive capabilities. ${ }^{15}$

The incidence of human metastatic melanoma is increasing and unfortunately presents low survival rates. Its treatment still poses a challenge, since currently available therapies present poor efficacy. ${ }^{16}$ Therefore, novel compounds that manage to decrease the viability of melanoma cells are needed. In this context, one strategy is to inhibit the autophagy process, which is linked to overexpressed signaling pathways. ${ }^{17}$

1,4-Naphthoquinones, quinolines, 1,3,5-triazines and morpholine were selected by our research group to design new hybrids with potential anticancer activity. These frameworks are present in drugs with recognized anticancer activity and different mechanisms, including cytotoxic and inhibitors of enzymes of signaling pathways. The 1,4-naphoquinones derivatives are widely studied due to their cytotoxic activity (e.g., inhibition of topoisomerase I and $\mathrm{II},{ }^{18,19}$ of p53 and Cdc25 phosphatase), ${ }^{20}$ besides the inhibition of PI3K. ${ }^{21}$ Compounds containing the quinoline nucleus also demonstrate activity inhibitory of protein kinases, such as PI3K, ${ }^{22} \mathrm{AMPK}^{23}$ and the growth factor receptors $(\mathrm{GFR})^{24}$ in addition to cytomechanisms like deoxyribonucleic acid (DNA) intercalant, ${ }^{25}$ antimitotic agents, ${ }^{26}$ inhibition of topoisomerase ${ }^{27}$ and telomerases..$^{28}$ On the other hand, 1,3,5-triazine derivatives, in turn, exhibit different targets in cancer chemotherapy, for example, the inhibition of PI3K, ${ }^{29}$ topoisomerase ${ }^{30}$ and Hsp90. ${ }^{31}$ Finally, morpholine group was chosen to compose the final set of molecular hybrids for two important reasons: besides its well-known contribution to anticancer activity (for example, PI3K and mammalian target of rapamycin (mTOR) inhibitor), ${ }^{32-35}$ it is responsible to enhance the solubility of 1,3,5-triazine intermediates, making it feasible to proceed to the next steps in a synthetic route, that is, characterization and biological evaluation. ${ }^{36}$

Drug design and discovery has been a challenge task that could demand a huge amount of time, reactants and human resource. To overcome these issues, computational chemistry provides helpful tools by gathering detailed information regarding the mechanism of action in a cheap and fast way. One of the most popular technique is molecular docking due its ability to model the interaction between drug candidates and their biomacromolecular targets. ${ }^{37,38}$ Several studies apply this technique to propose a rational drug design and its probable mechanism of action. $^{39-41}$

Based on the molecular hybridization concept and by the participation of the cited groups in the suppression of signaling pathways directly linked with carcinogenesis (e.g., PI3K and AMPK cascades), herein we decided to rationalize new molecules containing 1,4-naphthoquinone, 1,3,5-triazine and quinoline frameworks. Figure 1 depicts the target molecular hybrids (1-3) designed for this study. For 1,3,5-triazinic derivatives, the solubility of disubstituted intermediates is increased when it is attached to polar alicyclic groups..$^{29,36}$ Therefore, the morpholine ring was chosen for this purpose and due to its contribution to biological activity in substances with anticancer activity and inhibition of PI3K..$^{34,35}$ 1,3-Diaminopropane was selected to connect the frameworks. 2-Hydroxy1,4-naphthoquinone, 2,4,6-trichloro-1,3,5-triazine and 4,7-dichloroquinoline were selected as starting materials and are commercially available. Previously, molecular docking was simulated with PI3K and AMPK (Protein Data Bank (PDB) codes 1E7U ${ }^{42}$ and 2UV4, ${ }^{43}$ respectively) targets to verify its potential inhibitor character. Finally, we tested their cancer activity in human metastatic melanoma cells (SKMEL-103) and modulation of PI3K and AMPK expression.

\section{Experimental}

\section{General methods}

All solvents and starting materials were commercially available and used without any previous treatment. Melting points were determined using Fisatom 430D equipment. Infrared (IR) spectra were recorded on Bomem FTLA2000-102-ABB spectrometer. For the analysis of ${ }^{1} \mathrm{H}$ nuclear magnetic resonance (NMR) and ${ }^{13} \mathrm{C}$ NMR, the spectra were acquired on a Vary VNMRS spectrometer 


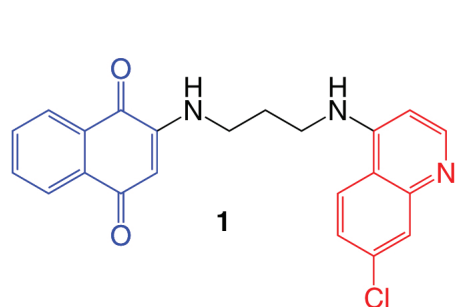<smiles>Clc1ccc2c(NCCCNc3nc(N4CCOCC4)nc(N4CCOCC4)n3)ccnc2c1</smiles>

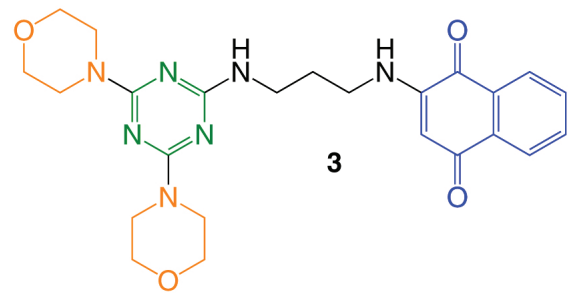

Figure 1. Molecular hybrids containing 1,4-naphthoquinone, 1,3,5-triazine, morpholine and quinoline cores.

model $400(400 \mathrm{MHz})$ with tetramethylsilane (TMS) as internal standard. NMR analysis of compounds $\mathbf{7}$ and $\mathbf{1 0}$ were performed in chloroform deuterated (99.8\%) with $1 \%(\mathrm{v} / \mathrm{v})$ of TMS and stabilized with silver foil (Cambridge Isotope Laboratories, Inc., Tewksbury, USA). For compounds 1, 2, 3 and 9, dimethyl sulfoxide (DMSO- $d_{6}$, Sigma-Aldrich, 99.9\%, São Paulo, Brazil) was used and for compound $\mathbf{8}$, a mixture 1:1 DMSO- $d_{6}: \mathrm{MeOD}$ was used (Aldrich 99.8\%, São Paulo, Brazil).

Mass spectra were recorded on a Bruker Daltonics model 9.4 T Solarix ultra-high resolution mass spectrometer (HRMS) operated in the negative and positive ionisation modes over a mass range of $\mathrm{m} / \mathrm{z} 200-2000$ using Fourier transform ion cyclotron resonance mass spectrometry (ESI-FT-ICR MS). ESI-FT-ICR MS spectra were acquired with a resolving power of $50 \%$ ca. 500000 , in which $50 \%$ is the full peak width at the half-maximum peak height of $\mathrm{m} / \mathrm{z}, 400$ and a mass accuracy of $<1 \mathrm{ppm}$, which provides an unambiguous molecular formula.

All the reactions were monitored by TLC (thin layer chromatography) using precoated silica gel aluminum plates containing a fluorescent indicator UV254 (Merck, São Paulo, Brazil).

\section{Synthesis}

\section{Preparation of 2-methoxylawsone (8)}

A suspension of lawsone $4(1.0 \mathrm{~g}, 5.7 \mathrm{mmol})$ in $50 \mathrm{~mL}$ of absolute methanol with concentrated chloridric acid $(0.8 \mathrm{~mL})$ was stirred at reflux for $4 \mathrm{~h}$. Then, the solution was allowed to obtain $\mathbf{8}$ as a palid yellow solid in $90 \%$; mp 179-180 ${ }^{\circ} \mathrm{C}$ (lit.: $182-183{ }^{\circ} \mathrm{C}$ ); IR (ATR) $\mathrm{V} / \mathrm{cm}^{-1} 3050$, 2991, 1680, 1643, 1603, 1214, 1044; ' $\mathrm{H}$ NMR (400 MHz, $\left.\mathrm{CDCl}_{3}\right) \delta 8.16-8.07(\mathrm{~m}, 2 \mathrm{H}), 7.76(\mathrm{~m}, 2 \mathrm{H}), 6.19(\mathrm{~s}, 1 \mathrm{H})$, $3.92\left(\mathrm{~s}, 3 \mathrm{H}, \mathrm{OCH}_{3}\right)$.
Preparation of $N^{1}$-(7-chloroquinolin-4-yl)propane1,3-diamine (9)

A suspension of 4,7-dichloroquinoline $5(2.0 \mathrm{~g}$, $10.1 \mathrm{mmol}$ ) in $4.2 \mathrm{~mL}$ of 1,3-diaminopropane was prepared heating the round bottom flask until $80^{\circ} \mathrm{C}$ for $1 \mathrm{~h}$ with no stirring. After that, the solution was stirred for $4 \mathrm{~h}$ at $120^{\circ} \mathrm{C}$ until full consumption of 4,7-dichloroquinoline, $\mathbf{5}$. At the end of the reaction, the brute material was transferred to a beaker and $20 \mathrm{~mL}$ of cold water with crushed ice was added. The precipitated was filtered and washed with $20 \mathrm{~mL}$ of cold water. In the following step, the solid was stirred with $15 \mathrm{~mL}$ of ethyl acetate and filtered under vacuum, furnishing a white solid in $87 \%$; mp $146-148{ }^{\circ} \mathrm{C}$ (lit.: 145-147 ${ }^{\circ} \mathrm{C}$ ); IR (ATR) v / $\mathrm{cm}^{-1} 3264,2936,2865,1586$, 1541, 1478, 1316, 1221, 1080, 800; ${ }^{1} \mathrm{H}$ NMR $(400 \mathrm{MHz}$, DMSO- $\left.d_{6} 1: 1 \mathrm{MeOD}\right) \delta 8.40(\mathrm{~d}, J 5.4 \mathrm{~Hz}, 1 \mathrm{H}), 8.18(\mathrm{~d}$, $J 9.0 \mathrm{~Hz}, 1 \mathrm{H}), 7.80(\mathrm{~d}, J 2.2 \mathrm{~Hz}, 1 \mathrm{H}), 7.46(\mathrm{dd}, J 9.0,2.2 \mathrm{~Hz}$, $1 \mathrm{H}), 6.59(\mathrm{~d}, J 5.4 \mathrm{~Hz}, 1 \mathrm{H}), 3.44(\mathrm{t}, J 7.0 \mathrm{~Hz}, 2 \mathrm{H}), 2.81$ (t, $J 7.0 \mathrm{~Hz}, 2 \mathrm{H}), 1.95-1.86(\mathrm{~m}, 2 \mathrm{H}) ;{ }^{13} \mathrm{C}$ NMR $(101 \mathrm{MHz}$, DMSO- $\left.d_{6}\right) \delta 152.3,150.5,149.4,133.7,127.9,124.4$, 124.4, 117.91, 99.0, 30.9.

Preparation of molecular hybrid 2-((3-((7-chloroquinolin4-yl)amino)propyl)amino)-naphthalene-1,4-dione (1)

Aminoquinoline 9 $(0.2360 \mathrm{~g}, 1 \mathrm{mmol})$ was solubilized in $20 \mathrm{~mL}$ of methanol at $70{ }^{\circ} \mathrm{C}$ with magnetic stirring. The temperature was reduced to $40^{\circ} \mathrm{C}$ and 2-methoxylawsone 8 $(0.1840 \mathrm{~g}, 1 \mathrm{mmol})$ was added with $140 \mu \mathrm{L}$ of triethylamine. After completion of reaction ( $48 \mathrm{~h}$ ), the solid was filtered and washed under vacuum with cold methanol. The product was obtained as an orange solid in $84 \%$; mp $210-212{ }^{\circ} \mathrm{C}$; IR (ATR) $\mathrm{v} / \mathrm{cm}^{-1} 3371,3066,2916,2865,1676,1614,1584$, $1279,1118,800,761,726 ;{ }^{1} \mathrm{H}$ NMR $\left(400 \mathrm{MHz}, \mathrm{DMSO}-d_{6}\right)$ $\delta 8.33(\mathrm{~d}, J 5.4 \mathrm{~Hz}, 1 \mathrm{H}), 8.20(\mathrm{~d}, J 9.0 \mathrm{~Hz}, 1 \mathrm{H}), 7.93(\mathrm{dd}$, $J$ 7.6, $0.9 \mathrm{~Hz}, 1 \mathrm{H}), 7.89(\mathrm{dd}, J 7.6,0.9 \mathrm{~Hz}, 1 \mathrm{H}), 7.78(\mathrm{td}$, 
$J$ 7.5, $1.3 \mathrm{~Hz}, 1 \mathrm{H}), 7.73(\mathrm{~d}, J 2.2 \mathrm{~Hz}, 1 \mathrm{H}), 7.68$ (td, J 7.5, $1.3 \mathrm{~Hz}, 1 \mathrm{H}), 7.61(\mathrm{t}, J 6.1 \mathrm{~Hz}, 1 \mathrm{H}), 7.40(\mathrm{dd}, J 9.0,2.2 \mathrm{~Hz}$, $1 \mathrm{H}), 7.29$ (t, J $5.3 \mathrm{~Hz}, 1 \mathrm{H}), 6.47$ (d, J $5.5 \mathrm{~Hz}, 1 \mathrm{H}), 5.70(\mathrm{~s}$, $1 \mathrm{H}), 1.94$ (q, $J 6.7 \mathrm{~Hz}, 2 \mathrm{H}) ;{ }^{13} \mathrm{C}$ NMR (101 MHz, DMSO- $\left.d_{6}\right)$ $\delta$ 181.9, 181.7, 152.2, 150.4, 149.4, 148.9, 135.2, 133.8, $133.5,132.5,130.8,127.8,126.3,125.7,125.4,124.4$, 124.4, 117.8, 99.8, 99.1, 26.3.

Preparation of 4,4-(6-chloro-1,3,5-triazine-2,4-diyl) dimorpholine (10)

Cyanuric chloride 6 (9.22 g, $50 \mathrm{mmol}), 50 \mathrm{~mL}$ of acetone, crushed ice $(250 \mathrm{~g})$, triethylamine $(15 \mathrm{~g}, 20 \mathrm{~mL})$ and morpholine $7(8.70 \mathrm{~g}, 100 \mathrm{mmol})$ was added in a round bottom flask under magnetic stirring at room temperature. After $2 \mathrm{~h}, 100 \mathrm{~mL}$ of distilled water at room temperature was added and the solid was filtered under vacuum and washed with cold distilled water. The product was obtained as a white solid in $93 \%$; $\mathrm{mp} 171-172{ }^{\circ} \mathrm{C}$ (lit.: $175-176{ }^{\circ} \mathrm{C}$ ); IR (ATR) v / $\mathrm{cm}^{-1} 2852,1566,1486,1448,1243,1113$, 978, 797; ${ }^{1} \mathrm{H}$ NMR (400 MHz, DMSO- $\left.d_{6}\right) \delta 3.62(\mathrm{~m}, 4 \mathrm{H})$, $3.56(\mathrm{~m}, 4 \mathrm{H}) ;{ }^{13} \mathrm{C}$ NMR (101 MHz, DMSO- $\left.d_{6}\right) \delta 169.1$, 164.2, 66.2, 43.9 .

Preparation of molecular hybrid $N^{1}$-(7-chloroquinolin4-yl)- $N^{3}$-(4,6-dimorpholine-1,3,5-triazin-2-yl)propane1,3-diamine (2)

Aminoquinoline $9(0.1180 \mathrm{~g}, 0.5 \mathrm{mmol})$ was solubilized in a round bottom flask with $20 \mathrm{~mL}$ of acetonitrile under reflux and magnetic stirring. The intermediate $10(0.1430 \mathrm{~g}$, $0.5 \mathrm{mmol}$ ) and triethylamine $70 \mu \mathrm{L}$ was then added. After $16 \mathrm{~h}$, the solid was filtered under vacuum and washed with cold distilled water, furnishing a white solid which was purified with chromatographic column (silica gel as stationary phase and $10 \% \mathrm{MeOH} / \mathrm{AcOEt}$ as eluent). The pure product was obtained as a white solid in $43 \%$; $\mathrm{mp} 230-231^{\circ} \mathrm{C}$; IR (ATR) v / $\mathrm{cm}^{-1} 3360,2965,2862,1546$, 1477, 1446, 1259, 1259, 1108, 808; ${ }^{1} \mathrm{H}$ NMR (400 MHz, DMSO- $\left.d_{6}\right) \delta 8.33(\mathrm{~d}, J 5.4 \mathrm{~Hz}, 1 \mathrm{H}), 8.21(\mathrm{~d}, J 9.1 \mathrm{~Hz}, 1 \mathrm{H})$, $7.74(\mathrm{~d}, J 2.3 \mathrm{~Hz}, 1 \mathrm{H}), 7.41(\mathrm{dd}, J 9.1,2.3 \mathrm{~Hz}, 1 \mathrm{H}), 7.29$ (t, $J 5.5 \mathrm{~Hz}, 1 \mathrm{H}), 6.85(\mathrm{t}, J 5.9 \mathrm{~Hz}, 1 \mathrm{H}), 6.41(\mathrm{~d}, J 5.5 \mathrm{~Hz}, 1 \mathrm{H})$, $3.54(\mathrm{~m}, 4 \mathrm{H}), 3.44(\mathrm{~m}, 4 \mathrm{H}), 3.27(\mathrm{~m}, 4 \mathrm{H}), 1.82(\mathrm{~m}, 2 \mathrm{H})$; HRMS (ESI (+) FT-ICR MS) $\mathrm{m} / z$, calcd. for $\mathrm{C}_{23} \mathrm{H}_{30} \mathrm{ClN}_{8} \mathrm{O}_{2}$ $[\mathrm{M}+\mathrm{H}]^{+}:$485.21802, found: $485.21749($ error $=1.09 \mathrm{ppm})$; dimer calcd. for $\mathrm{C}_{46} \mathrm{H}_{59} \mathrm{Cl}_{2} \mathrm{~N}_{16} \mathrm{O}_{4}[2 \mathrm{M}+\mathrm{H}]^{+}$: 969.42822 , found: 969.42783 (error $=0.40 \mathrm{ppm}$ ).

Preparation of 2-((3-aminopropyl)amino)naphthaleno1,4-dione (11)

A suspension of 2-methoxylawsone $8(0.0941 \mathrm{~g}$, $0.5 \mathrm{mmol}$ ) in $10 \mathrm{~mL}$ of methanol, 1,3-diaminopropane $(84 \mu \mathrm{L}, 0.07472 \mathrm{~g}, 1.0 \mathrm{mmol})$ and $0.084 \mathrm{~mL}$ of triethylamine
$(0.6 \mathrm{mmol})$ was added in a round bottom flask and magnetically stirred for $24 \mathrm{~h}$ at room temperature. An aliquot of $15 \mathrm{~mL}$ of distilled water was then slowly added, furnishing the pure product as an orange solid in $61 \% ; \mathrm{mp}$ 124-126 ${ }^{\circ} \mathrm{C}$ (lit.: $124-126{ }^{\circ} \mathrm{C}$ ); IR (ATR) v / $\mathrm{cm}^{-1} 3355$, 2933, 1682, 1670, 1642, 1566, 1243; ${ }^{1} \mathrm{H}$ NMR $(400 \mathrm{MHz}$, DMSO- $\left.d_{6}\right) \delta 8.08(\mathrm{dd}, J 7.6,0.9 \mathrm{~Hz}, 1 \mathrm{H}), 8.02(\mathrm{dd}, J 7.6$, $0.9 \mathrm{~Hz}, 1 \mathrm{H}), 7.70(\mathrm{td}, J 7.6,1.3 \mathrm{~Hz}, 1 \mathrm{H}), 7.59(\mathrm{td}, J$ 7.6, $1.3 \mathrm{~Hz}, 1 \mathrm{H}$ ), 6.83 (br s, 1H), 3.27 (dd, $J 12.3,6.4 \mathrm{~Hz}, 2 \mathrm{H}$ ), 2.89 (t, J 6.4 Hz, 2H), 1.81 (q, J $6.4 \mathrm{~Hz}, 2 \mathrm{H})$.

Preparation of molecular hybrid 2-((3-((4,6-dimorpholine1,3,5-triazin-2-yl)amino)propyl)amino)naph-thalene1,4-dione (3)

The aminonaphthoquinone 11 (0.1150 g, $0.5 \mathrm{mmol})$ was solubilized in $20 \mathrm{~mL}$ of acetonitrile under magnetic stirring and at reflux in a round bottom flask. The intermediate $10(0.1430 \mathrm{~g}, 0.5 \mathrm{mmol})$ and $70 \mu \mathrm{L}$ of triethylamine was then added. After $16 \mathrm{~h}$ of reflux, the content was filtered under vacuum. The brute product was recrystallized in hot ethanol to furnish the pure product as a yellow solid in $47 \%$; mp $210-212{ }^{\circ} \mathrm{C}$; IR (ATR) $\mathrm{v} / \mathrm{cm}^{-1}$ 3337, 2979, 2855, 1679, 1606, 1547, 1446, 1252, 1106, 1006, 803; ${ }^{1} \mathrm{H}$ NMR (400 MHz, DMSO- $\left.d_{6}\right) \delta 7.97$ (dd, $J$ 7.4, $6.6 \mathrm{~Hz}, 1 \mathrm{H}), 7.94(\mathrm{~m}, 1 \mathrm{H}), 7.82(\mathrm{td}, J 7.4,1.2 \mathrm{~Hz}$, 1H), $7.72(\mathrm{td}, J$ 7.4, $1.2 \mathrm{~Hz}, 1 \mathrm{H}), 7.39$ (br s, 1H), 6.73 (s, 1H), $5.65(\mathrm{~s}, 1 \mathrm{H}), 3.57$ (m, 8H), 3.53 (br s, 8H), 3.23 (m, 4H), $1.81(\mathrm{~m}, 2 \mathrm{H}) ;{ }^{13} \mathrm{C}$ NMR (101 MHz, DMSO- $\left.d_{6}\right)$ $\delta$ 181.5, 181.1, 165.7, 164.7, 148.4, 134.8, 133.2, 132.1, 130.3, 125.8, 125.3, 99.2, 65.9, 43.1, 37.6, 27.4; HRMS (ESI (+) FT-ICR MS) $m / z$, calcd. for $\mathrm{C}_{24} \mathrm{H}_{30} \mathrm{~N}_{7} \mathrm{O}_{4}[\mathrm{M}+\mathrm{H}]^{+}$: 480.23538, found: 480.23504 (error $=0.71 \mathrm{ppm}$ ); calcd. for $\left[\mathrm{C}_{24} \mathrm{H}_{29} \mathrm{~N}_{7} \mathrm{O}_{4}+\mathrm{Na}\right]^{+}$: 502.21732, found: 502.21705 (error $=0.54 \mathrm{ppm}$ ); dimer calcd. for $\mathrm{C}_{48} \mathrm{H}_{59} \mathrm{Cl}_{2} \mathrm{~N}_{14} \mathrm{O}_{8}[2 \mathrm{M}+\mathrm{H}]^{+}$: 959.46348 , found: 959.46281 (error $=0.70 \mathrm{ppm}$ ); calcd. for $\left[\mathrm{C}_{48} \mathrm{H}_{58} \mathrm{~N}_{14} \mathrm{O}_{8}+\mathrm{Na}\right]^{+}$: 981.44543, found: 981.44450 (error $=0.95 \mathrm{ppm}$ ).

\section{Anticancer activity}

\section{Reagents}

Compounds tested were obtained as described below. Reagents for western blotting were purchased from BioRad (Hercules, CA, USA) and Sigma-Aldrich (St. Louis, MO, USA). Primary and HRP-conjugated secondary antibodies were purchased from Cell Signaling Technology (Beverly, MA, USA), Santa Cruz (St. Louis, MO, USA), Sigma-Aldrich (St. Louis, MO, USA) and BIOSS (Boston, MA, USA). MTT (methylthiazolyldiphenyl-tetrazolium bromide) was purchased from Sigma-Aldrich (St. Louis, MO, USA). 


\section{Cell culture}

Melanoma metastatic cells (SKMEL-103) were kindly donated by Prof Silvya Stuchi Maria Engler from São Paulo University (Brazil). Cells were routinely grown in Dulbecco's modified Eagle's medium (DMEM) containing

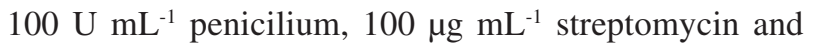
$10 \%$ fetal bovine serum (FBS), in a $5 \% \mathrm{CO}_{2}$ humidified atmosphere, at $37^{\circ} \mathrm{C}$.

\section{Treatment of melanoma cells}

SKMEL-103 cells $\left(100 \mu \mathrm{L}\right.$ of $7 \times 104$ cells $\mathrm{mL}^{-1}$ suspension) were cultured in a 96-wells microplate for $24 \mathrm{~h}$, subsequently the cells were treated with different concentrations of the compounds for $24 \mathrm{~h}$. A stock solution of compounds was prepared in DMSO and control group was treated with the equivalent amount of DMSO. Cell viability was assessed by MTT reduction assay as described below. Non-treated cell viability was set as $100 \%$ and half maximal inhibitory concentration $\left(\mathrm{IC}_{50}\right)$ values were determined from three independent experiments.

\section{MTT reduction assay}

Treatment medium was removed and the cells incubated with $100 \mu \mathrm{L}$ well ${ }^{-1}$ of MTT solution $\left(0.5 \mathrm{mg} \mathrm{mL}^{-1}\right.$, in FBS free culture medium) for $2 \mathrm{~h}$ at $37^{\circ} \mathrm{C}$. Hereafter, the MTT solution was removed and the formazan produced was dissolved with $100 \mu \mathrm{L}$ of ethanol. Microplate was shaken for $10 \mathrm{~min}$ and the absorbance of formazan was determined at $570 \mathrm{~nm}$ in a microplate reader (Synergy HT, BioTek). The measured absorbance at $570 \mathrm{~nm}$ was normalized to percentage of control. This value was calculated by multiplying the absorbance of a treated well by 100 and dividing it by the average absorbance of control wells.

\section{Western blotting}

SKMEL-103 (10 mL of $15 \times 104$ cells $\mathrm{mL}^{-1}$ suspension) were cultured in a $100 \mathrm{~mm}$ plates for $24 \mathrm{~h}$, afterwards the cells were treated with compounds solutions in $0.05 \%$ DMSO for $24 \mathrm{~h}$. The control group was treated with the equivalent amount of DMSO. After the treatment, the cells was removed from plates by using a rubber policeman, centrifuged and lysed for $2 \mathrm{~h}$ on ice in cell lysis buffer (50 mM Tris- $\mathrm{HCl}$, pH 7.4 containing 1\% Tween 20, $0.25 \%$ sodium deoxycholate, $150 \mathrm{mM} \mathrm{NaCl}, 1 \mathrm{mM}$ EGTA (ethyleneglycotetraacetic acid), $1 \mathrm{mM} o$-vanadate, $1 \mathrm{mM} \mathrm{NaF}, 1 \mu \mathrm{g} \mathrm{mL}^{-1}$ aprotinin, $10 \mu \mathrm{g} \mathrm{mL}^{-1}$ leupeptin and $1 \mathrm{mM}$ PMSF (phenylmethylsulfonyl fluoride)). Then, the cell lysate was cleared by centrifugation and the protein concentration was determined using Bradford reagent (Sigma-Aldrich). An equal volume of $2 \times$ sodium dodecyl sulfate (SDS) gel loading buffer (100 mM Tris-HCl, pH 6.8, $200 \mathrm{mM}$ dithiothreitol (DTT), 4\% SDS, $0.1 \%$ bromophenol blue and $20 \%$ glycerol) was added and the samples were boiled for $5 \mathrm{~min}$. The corresponding to $100 \mu \mathrm{g}$ of protein was resolved by SDS-polyacrylamide gel (8-12\%) eletrophoresis (PAGE) and transferred to polyvinylidene difluoride (PVDF) membrane. The membranes were blocked in bovine serum albumin $(5 \%)$ in tris-buffered saline (TBS)-Tween ${ }^{\circledR} 20(0.05 \%)$ and incubated overnight at $4{ }^{\circ} \mathrm{C}$ with appropriate primary antibody at $1: 1000$ dilution. After washing in TBS-Tween ${ }^{\circledR} 20(0.05 \%)$, the membranes were incubated with anti-rabbit, anti-mouse and anti-goat horseradish peroxide-conjugated secondary antibodies at 1:2000 dilutions for $2 \mathrm{~h}$. The detection was performed by using enhanced chemiluminescence in ImageQuantTM 350 (GE healthcare Life Sciences).

\section{Statistical analysis}

Results are expressed as mean \pm standard error of the mean (SEM). The statistical analyses were performed using analysis of variance (ANOVA) combined with Tukey's or Bonferroni's tests. $p$ value $>0.05$ was considered to be statistically significant with $* * * p<0.001, * * p<0.01$ and $* p<0.05 ;$ n.s. was not significant.

\section{Results and Discussion}

\section{Docking studies}

Docking studies were performed initially to check the interactions between the target molecules and the enzymes, followed by the chemical studies to synthesize the target substances.

Crystallographic studies of a series of enzymes complexes with their ligands have facilitated the rational design of new inhibitors, and they are available from the PDB. In our case, the PI $3 \mathrm{~K} \gamma$ crystal structure associated with the wortmannin ligand was obtained under code 1E7U (with resolution of $2.00 \AA$ ), ${ }^{42}$ and AMPK with ligand adenosine monophosphate, AMP, was obtained under code 2UV4 (resolution of $1.33 \AA$ ), ${ }^{43}$ crystal structures displayed in Supplementary Information (SI) section.

The accuracy of Autodock Vina ${ }^{44}$ was evaluated with respect to pose identification and database enrichment. In the pose identifications, crystallographic ligands were redocked against their respective receptors to evaluate the 
methodology (Figure 2). As a result, the root-mean-square deviation (RMSD) between docked and crystallographic structures were $1.53 \AA$ (Figure 2a) and $0.51 \AA$ (Figure 2b) for wortmannin and AMP, respectively. As can be observed, Autodock Vina ${ }^{44}$ could reproduce pharmacophore conformation into the binding site of both molecular targets, and the threshold value is $2.0 \AA$.

Next, the methodology was evaluated as a database enrichment. Hence, 300 decoys, false-positive compounds, were docked for each molecular target obtained from the "Database of Useful Decoys: Enhanced (DUD-E)" database. As a result, the total area under receiver operation characteristic curves (AUC) ${ }^{45}$ showed good enrichment for both receptors (0.7). AUC values of 0.5 and below characterizes a random process and poor enrichment, respectively. In other words, Autodock Vina can discriminate false-positive from positive compounds (Figures $2 \mathrm{c}$ and $3 \mathrm{~d}$, suggesting the 1E7U and 2UV4 as molecular targets).

Sequentially, wortmannin ${ }^{42}$ and LY294002 (2-morpholin4-yl-8-phenylchromen-4-one) ${ }^{42}$ (control drugs for PI3K $\gamma$ ) and AICAR (5-aminoimidazole-4-carboxamide ribonucleotide $)^{46}$ and 6-chloro-5-(2'-hydroxy-3"-methoxy[1,1'-biphenyl]-4-yl)-3-(3-methoxyphenyl)-1,5-dihydro$2 H$-pyrrolo[3,2-d]pyrimidine-2,4(3H)-dione (GSK621) $)^{47}$ (control drugs for AMPK), after previous optimization with molecular mechanics, ${ }^{47}$ were superimposed on the binding

(a)

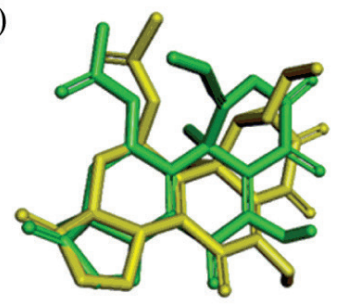

1E7U - ROC Curve

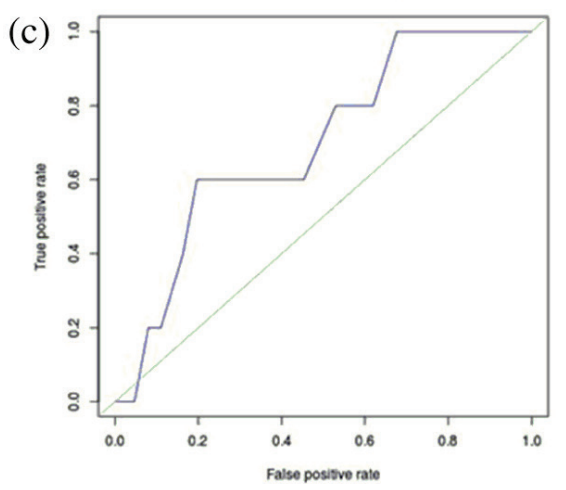

site of the receptor, the ATP (adenosine triphosphate) cleft, via the same method, furnishing the calculated interaction energy ligand/receptor (Table 1) ${ }^{44}$ Next, compounds $\mathbf{1}, \mathbf{2}$ and $\mathbf{3}$ were docked into the binding site using the same methodology.

Table 1. Ligand / receptor interaction energies of compounds against respective molecular targets

\begin{tabular}{lcc}
\hline \multirow{2}{*}{ Compound } & \multicolumn{2}{c}{ Interaction energy / $\left(\mathrm{kcal} \mathrm{mol}^{-1}\right)$} \\
\cline { 2 - 3 } & PI3K $\gamma$ & AMPK \\
\hline Wortmannin & -8.7 & - \\
LY294002 & -8.5 & - \\
AICAR & - & -6.5 \\
GSK621 & - & -6.7 \\
$\mathbf{1}$ & -8.8 & -6.2 \\
$\mathbf{2}$ & -8.3 & -7.5 \\
$\mathbf{3}$ & -9.2 & -8.1 \\
\hline
\end{tabular}

PI3K $\gamma$ : phosphoinositide 3-kinase; AMPK: 5'AMP-activated protein kinase; LY294002: 2-morpholin-4-yl-8-phenylchromen-4-one; AICAR: 5-aminoimidazole-4-carboxamide ribonucleotide; GSK621: 6-chloro5-(2'-hydroxy-3'-methoxy-[1,1'-biphenyl]-4-yl)-3-(3-methoxyphenyl)1,5-dihydro- $2 H$-pyrrolo[3,2-d]pyrimidine-2,4(3H)-dione.

Table 1 shows that all designed hybrids $(\mathbf{1}, \mathbf{2}$ and $\mathbf{3})$ had interaction energies close or better than those exhibited by the control drugs. Supposedly, these hybrids present the same potential inhibitory activity of PI $3 \mathrm{~K} \gamma$ and AMPK of the control drugs, or even better, which means that the

(b)
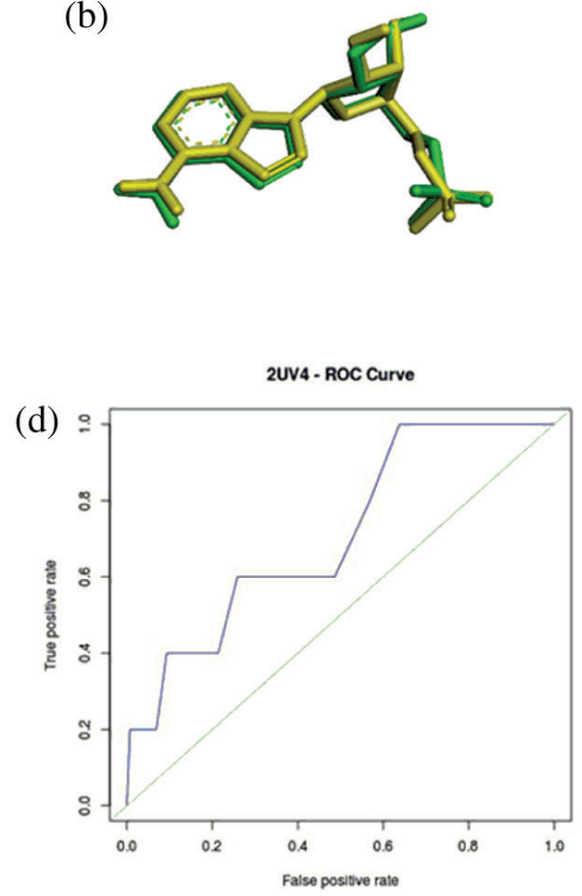

Figure 2. Evaluation of Autodock Vina ${ }^{44}$ methodology (hydrogen atoms were omitted for a better visualization). Crystallographic ligands (yellow) and the redocked structures (green); (a) wortmannin (PI3K $\gamma$ : 1E7U, PDB); (b) AMP (AMPK: 2UV4, PDB); (c) and (d) roc curve for 1E7U and 2UV4, respectively, both with 0.7 value. 
anticancer mechanism of action could be by the inhibition of these enzymes beyond other mechanisms possible for the isolated groups already described. ${ }^{18-35}$

The compound 1-3 bind strongly to receptors as inferred by its minimum binding energy value (Table 1). The best result was obtained to molecular hybrid of $\mathbf{3}(-9.2$ and $-8.1 \mathrm{kcal} \mathrm{mol}^{-1}$ ) in PI3K $\gamma$ and AMPK, respectively. However, the other compounds also obtained good binding energies, demonstrating the promising potential of these hybrids. The results obtained from the docking studies permitted us to evaluate the pharmacophoric conformation of control drugs inside the binding site of the enzymes. Therefore, it was possible to analyze which amino acids residues are important to the interactions energy established

(a)

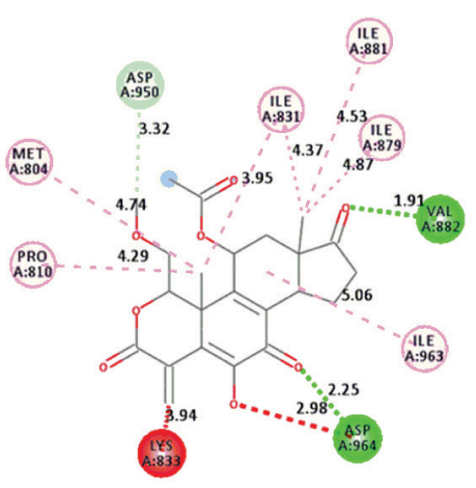

(c)

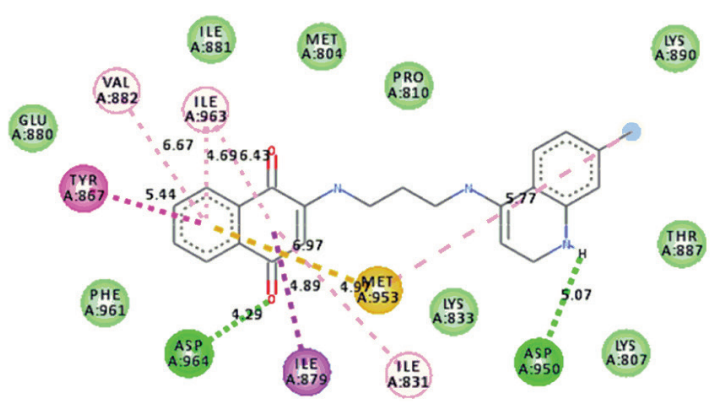

(e)

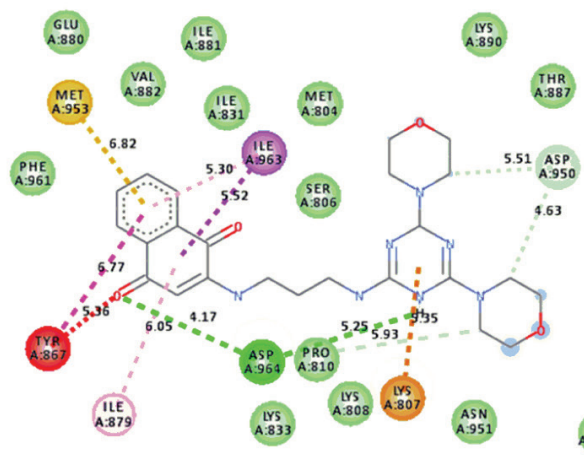

between the enzyme and the ligands as well as the type of interaction (van der Waals, electrostatic, hydrogen bonding, among others).

Figure 3 depicts the intermolecular interaction between ligands and 1E7U (PI3K $\gamma$ in 2D diagram). As can be observed, the wortmannin control drug can bind to PI3K $\gamma$ by van der Waals interactions with the amino Asp950; electrostatic interactions with Met804, Pro810, Ile831, Ile881, Ile879 and Ile963 amino acid residues; and hydrogen bonding with Val882 and Asp964 amino acids. In addition, an unfavorable interaction was carried out with Lys833, as shown in Figure 3a.

The pharmacophoric conformation of LY294002 is demonstrated in Figure 3b. Van der Waals interactions are

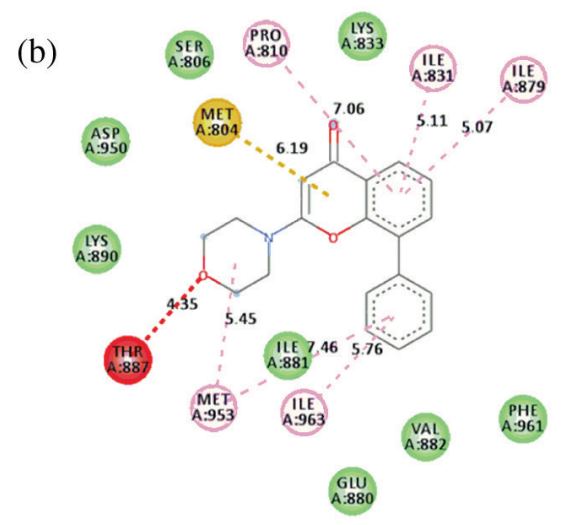

(d)
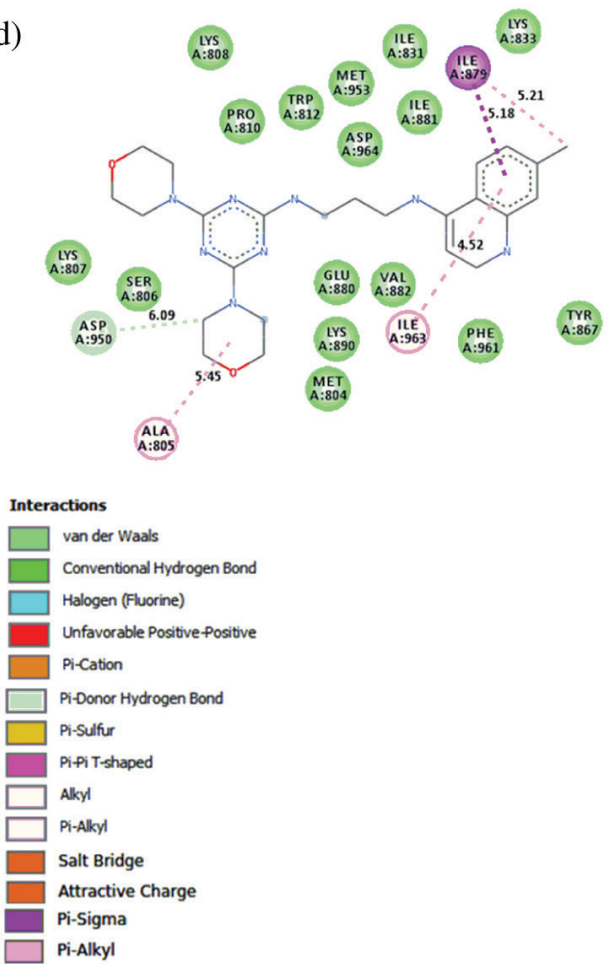

Figure 3. 2D intermolecular interaction diagram among ligands and PI3K $\gamma$. (a) Wortmannin; (b) LY294002; (c) hybrid naphthoquinone-quinoline 1; (d) 2; (e) 3. The distance is in angstroms $(\AA)$ and the hydrogens were omitted for a better visualization. 
found in the binding site of the enzyme with the amino acids residues (i.e., Ser806, Glu880, Lys833, Ile881, Val882, Lys890, Asp950 and Phe961), and electrostatic interactions were found with Pro810, Ile831, Ile879, Met953 and Ile963 amino acids residues. In addition, a $\pi$-sulfur interaction was observed with Met804. In contrast, an unfavorable interaction was carried out with Thr887. No hydrogen bonding was observed in this case.

The hybrid naphthoquinone-quinoline $\mathbf{1}$ exhibited values for interaction energy of $-8.4 \mathrm{kcal} \mathrm{mol}^{-1}$; this was similar to the control drugs wortmannin and LY294002, which exhibited -8.7 and $-8.5 \mathrm{kcal} \mathrm{mol}^{-1}$, respectively, for PI3K $\gamma$. The interactions for the complex hybrid 1/PI3K $\gamma$ are displayed in Figure 3c, which consist of van der Waals interactions with Met804, Lys807, Pro810, Glu880, Lys833, Thr887, Lys890 and Phe961 amino acids and electrostatic interactions with Ile831, Tyr867, Ile879, Val882, Met953 and Ile963 amino acids. Asp950 and Asp964 also established hydrogen bonding with the quinoline nitrogen and naphthoquinone carbonyl, respectively.

In addition, the morpholine, triazine and quinoline hybrid 2 containing moieties can perform intermolecular interactions with $\mathrm{PI} 3 \mathrm{~K} \gamma$, which has the best interaction energy among the compounds studied (-9.1 kcal mol$\left.{ }^{-1}\right)$. For the complex with PI3K $\gamma$, the observed interactions included the following: van der Waals interactions with Ser806, Lys807, Lys808, Pro810, Trp812, Ile831, Tyr867, Glu880, Ile881, Val882, Met804, Lys833, Lys890, Asp950 and Phe961 amino acids and electrostatic interactions with Ala805, Ile879 and Ile963 (Figure 3d).

Furthermore, the hybrid $\mathbf{3}$, like $\mathbf{1}$ and $\mathbf{2}$, carried out van de Waals interactions with PI3K $\gamma$. Furthermore, this molecular target recognized that the hybrid 3, like $\mathbf{1}$ and 2, carried out van der Waals interactions with PI3K $\gamma$. This molecular target recognized 3 through Ser806, Met804, Lys808, Pro810, Lys833, Glu880, Ile881, Val882, Ile831, Thr887, Lys890, Asp950, Asn951, Phe961 and Leu1090. In addition, it could have performed electrostatic interactions with Lys807, Met953 and Ile963 and a hydrogen bond with Asp964. On the other hand, it carried out an unfavorable interaction with Tyr867 amino acids (Figure 3e).

In a similar way to PI3K $\gamma$ enzyme, Figure 4 shows the intermolecular interactions between AMPK and ligands. The AICAR complex with AMPK through van der Waals interactions with Ile204, Val225, Leu228 and Ile312 amino acid residues. Electrostatic interactions are formed with Thr200, Asn203, Ala205, Ser226, Ala227, Ser314, Ser316 and Asp317 amino acids. In addition, six hydrogen bonds were formed between amide portion of AICAR and Ala205, Ala227, Ser226 and finally with Asp317 (Figure 4a).
The control drug GSK demonstrated van der Waals interactions with Ala202, Ile204, Ala205, Val225 and Ile312 amino acids, electrostatic interactions with Thr200, Asn203, His223, Ser314, Asp317 and Gln320amino acids. Moreover, Ser314 and Gln320 performed two hydrogen bonding. Finally, it was also found a $\pi-\pi^{*}$ stacking with His223 (Figure 4b).

For the AMPK complex, compound 1 showed the following interactions (Figure 4c): van der Waals interactions with Ala205, Thr200, Ser314, Asp317 (centered on aliphatic chain) and electrostatic interactions with Ile204, Val225 and Ile312 amino acids, principally with the naphthoquinone core. Hydrogen bonding was carried out with carbonyl and Ser226.

The hybrid-containing morpholine ring gathered with triazine and the naphthoquinone cores of compound $\mathbf{2}$ could form a complex with AMPK by a van der Waals interaction with His298; electrostatic interactions were apparent with amino acids Thr200, Ile204 and Ile312 (Figure 4d).

Finally, inside the binding site of AMPK and $\mathbf{3}$, there were van der Waals interactions with Thr200, Asn203, Ser314 and Ser316 residues and electrostatic interactions with Ile204, Ala205, Val225 and Ile312 amino acids. A hydrogen bond was formed between the oxygen atom of the morpholine ring His298 residue (Figure 4e).

In addition, in both cases, the hybrid compounds share similar electrostatic and van der Waals intermolecular interactions with each other and with control drugs. Thus, the binding site cavity of both targets were highlighted with compound 3 (Figure 5). As can be observed, it depicts a close and open cavity for PI3K $\gamma$ and AMPK, respectively. It is noteworthy that both share two distinct regions, one hydrophobic in which the naphthoquinone ring binds, and other hydrophilic region that the triazine and morpholine rings bind. In other words, triazine and quinoline moieties have become protonated in physiologic $\mathrm{pH}$, addressing these groups for the polar region of the binding site. These findings explain the high affinity of hybrids for both PI3K $\gamma$ and the AMPK molecular target.

\section{Chemical results}

After the satisfactory results of the previous analysis of ligand / enzyme interaction energy, the synthetic part of the work was started. The starting materials chosen to synthesize the target molecular hybrids (1, 2 and $\mathbf{3}$ ) were lawsone 4, 4,7-dichloroquinoline 5, cyanuric chloride $\mathbf{6}$ and morpholine 7, which are all commercially available (Figure 6).

Initially, the preparation of 2-methoxylawsone $\mathbf{8}$, the electrophile precursor to achieve hybrid $\mathbf{1}$, was made 
(a)

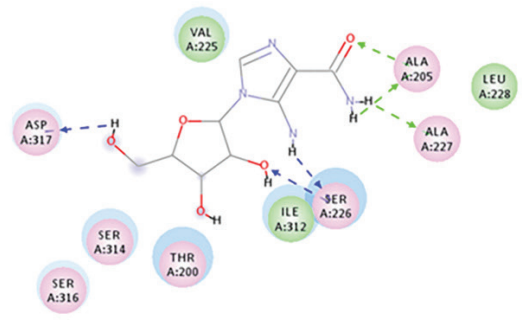

(c)

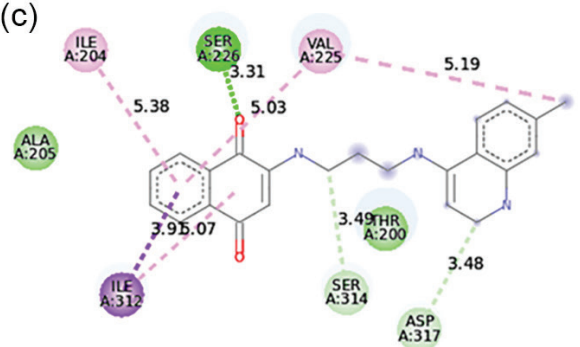

(e)

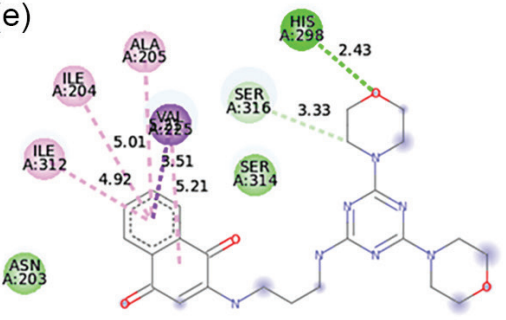

A:RR日

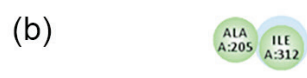

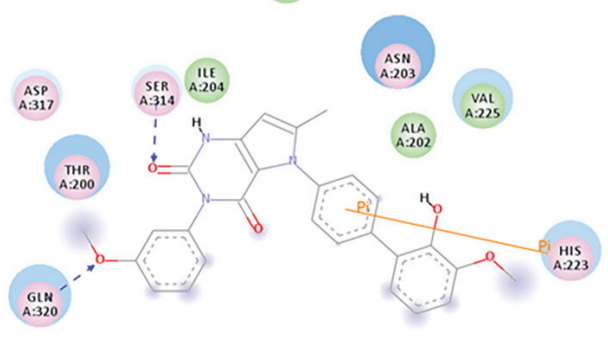

(d)
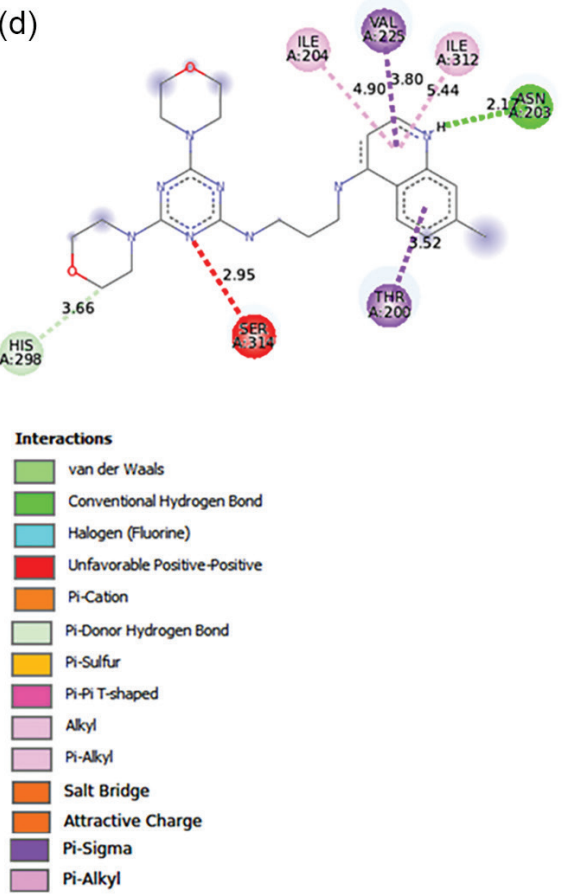

Figure 4. 2D intermolecular interaction diagram among ligands and AMPK. (a) AICAR; (b) GSK621; (c) naphthoquinone-quinoline hybrid 1; (d) 2; (e) 3. The distance is in angstroms $(\AA)$ and the hydrogens were omitted for a better visualization.
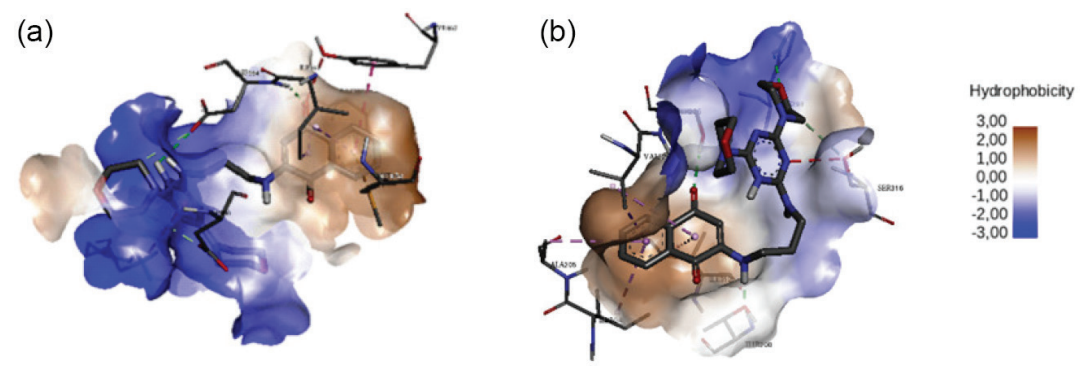

Figure 5. Hydrophobic receptor surface complex with hybrid compound 3. (a) With PI3K $\gamma$ and (b) with AMPK.<smiles>O=C1C=C(O)C(=O)CC1=O</smiles>

4<smiles>Clc1ccc2c(Cl)ccnc2c1</smiles>

5<smiles>Clc1nc(Cl)nc(Cl)n1</smiles>

6<smiles>CC1C2CCC1OCCN2</smiles>

7

Figure 6. Starting materials for synthesis of molecular hybrids $\mathbf{1 , 2}$ and $\mathbf{3}$.

following a procedure that has been previously published. ${ }^{44}$ The lawsone was solubilized in methanol containing hydrochloric acid and then maintained under reflux conditions for four hours to form compound $\mathbf{8}$ as a yellow solid with $90 \%$.

In the following step, 4,7-dichloroquinoline $\mathbf{5}$ was converted into $\mathbf{9}$, the nucleophile for the further step, 
according to the procedure described by Carmo et al. ${ }^{48}$ The reaction was performed with excess of 1,3-diaminopropane at a temperature of $80-110^{\circ} \mathrm{C}$ for $4 \mathrm{~h}$ to form the corresponding aminoquinoline 9 in $87 \%$ yield as a solid white.

Finally, the intermediates 8 and $\mathbf{9}$ were submitted to synthesize the target molecular hybrid $\mathbf{1}$. The conditions are displayed in Figure 7. The temperature was maintained between 40 and $50{ }^{\circ} \mathrm{C}$ with the purpose of keeping the reactants as soluble as possible. It is noteworthy that the best result in terms of yield was obtained when $\mathrm{MeOH}$ (entry $3,84 \%$ ) was used as the solvent. It may have occurred because of its intermediate polarity and dielectric constant compared to EtOH (entry 1, 15\%) and $\mathrm{H}_{2} \mathrm{O}$ (entry 2,14\%), allowing a better solubility of the reactants. Surprisingly, the reaction time when water is used as the solvent (entry 2) is drastically reduced considering the other solvents. In a recent work of our research group, ${ }^{49}$ we discussed the preparation of 1,4-naphthoquinonic derivatives in aqueous media and its effects: it is possible that, since the compounds are hydrophobic, the frequency of effective collisions is enhanced once they are repelled by water molecules and forced to approach (hydrophobic effect), resulting in the diminish of reaction time due to statistical reasons.

The mechanism for the formation of $\mathbf{1}$ should resemble the mechanism that was recently proposed by our research group (Figure 8)..$^{50}$ The tetrahedral species, commonly suggested as an intermediate in addition-elimination mechanism of substitution reactions, is not stable or may decompose with low activation energy. Therefore, reactions occur in either a single asynchronous step involving a simultaneous addition-elimination process that describes an uncoupled $\mathrm{S}_{\mathrm{N}} 2$, with one step and two stages, in which the second stage (break of the carbon-leaving group bond) occurs with low or no activation energy.

For the next hybrid, morpholine-triazine-quinoline 2, the intermediate nucleophilic $\mathbf{9}$, which was already prepared, reacts with the electrophilic intermediate $\mathbf{1 0}$<smiles>COC1=CC(=O)c2ccccc2C1=O</smiles>

Figure 7. Synthesis of target molecular hybrid $\mathbf{1}$.<smiles>COC1=CC(=O)c2ccccc2C1=O</smiles>

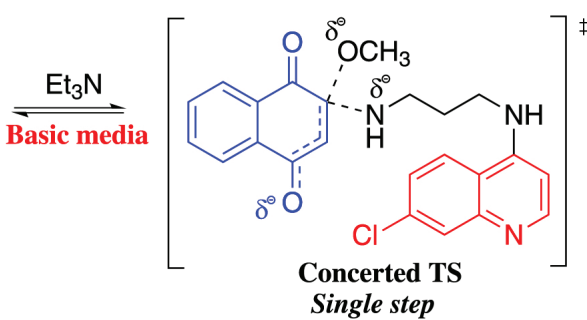<smiles>O=C1C=C(NCCCNc2ccnc3cc(Cl)ccc23)C(=O)c2ccccc21</smiles>

Figure 8. Proposed mechanism for synthesis molecular hybrid $\mathbf{1}$. 
formed by the reaction between cyanuric chloride $\mathbf{6}$ and two equivalents of morpholine 7. Therefore, cyanuric chloride reacted with morpholine in presence of triethylamine and acetone at $0{ }^{\circ} \mathrm{C}$ and held at room temperature for $2 \mathrm{~h}$ to form $\mathbf{1 0}$ as a pure white solid in $93 \%$ yield. ${ }^{35}$ The bismorpholino1,3,5-triazine scaffold have an advantage, therefore, one morpholine gets metabolically oxidized, still leaving another morpholine to make, a possible, $\mathrm{H}$ bond interaction with the receptor proteins. Another important function of morpholine is to increase the solubility of the intermediate in usual organic solvents, facilitating the homogeneity of subsequent reactions..$^{51,52}$

Posteriorly, intermediate 10 reacted with 9 in $\mathrm{CH}_{3} \mathrm{CN}$ in presence of $\mathrm{Et}_{3} \mathrm{~N}$ under reflux for $16 \mathrm{~h}$, furnishing the desired molecular hybrid $\mathbf{2}$ with a yield of $43 \%$ (Figure 9).

Once the electrophilic intermediate $\mathbf{1 0}$ was synthesized, compound 11 (the nucleophile to obtain the molecular hybrid 3) was prepared following a procedure described by our research group earlier (Figure 10). ${ }^{49}$ In the following step, the target molecular hybrid $\mathbf{3}$ was obtained with yield of $47 \%$ in $16 \mathrm{~h}$ (Figure 10). The synthesis of the molecular hybrids $\mathbf{2}$ and $\mathbf{3}$ follows the same mechanistic purpose: a nucleophilic aromatic substitution.
The characterization of the final molecular hybrids $\mathbf{1}$, $\mathbf{2}$ and $\mathbf{3}$ proved their formation. For 1, Fourier transform infrared (FTIR), ${ }^{1} \mathrm{H}$ and ${ }^{13} \mathrm{C}$ NMR spectroscopies were used to show the coupling of naphthoquinone and quinoline cores. The ${ }^{1} \mathrm{H}$ NMR spectrum showed all the signals observed in the precursors $\mathbf{8}$ and $\mathbf{9}$, except the singlet at $\delta 3.92 \mathrm{ppm}$ due to $\mathrm{OCH}_{3}$ from 2-methoxylawsone (8), which was substituted in the reaction displayed in Figure 7.

For hybrids $\mathbf{2}$ and $\mathbf{3}$, however, high-resolution mass spectrometry was necessary to prove the number and type of substituents in the triazine core, i.e., to detect two morpholine groups and one quinoline (in case of hybrid 2) or one naphthoquinone (for hybrid 3). In spectra of hybrid 2, two important peaks were found: one in $485.21749 \mathrm{~m} / \mathrm{z}$, with error of $1.09 \mathrm{ppm}$, which was related to the protonated structure of 2 , and $969.42783 \mathrm{~m} / \mathrm{z}$ with error of $0.40 \mathrm{ppm}$, which was associated with its protonated dimer. In spectra of hybrid $\mathbf{3}$, two peaks were also found: one for the protonated monomer (480.23504 $\mathrm{m} / \mathrm{z}$, with error of $0.71 \mathrm{ppm}$ ) and one for the protonated dimer $(959.46281 \mathrm{~m} / \mathrm{z}$ with error of $0.70 \mathrm{ppm})$.

After obtaining the target molecular hybrids 1, 2 and $\mathbf{3}$, we attempted to reach a molecular hybrid containing morpholine, naphthoquinone, quinoline and triazine cores<smiles>[Y16][Y16]([H])(C)NCCCNc1ccnc2cc(Cl)ccc12</smiles>

Figure 9. Synthesis of target molecular hybrid 2.<smiles>CCN(CC)CCCCN</smiles>

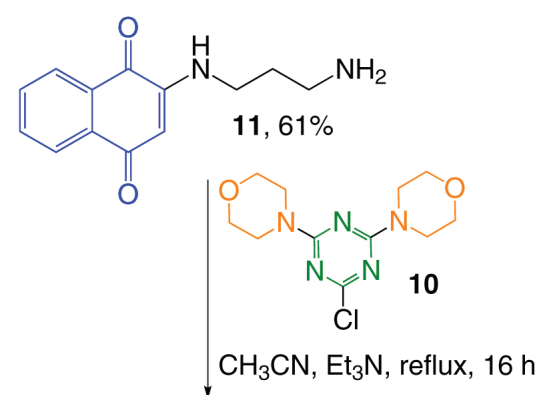<smiles>O=C1C=C(NCCCNc2nc(N3CCOCC3)nc(N3CCOCC3)n2)C(=O)c2ccccc21</smiles>

Figure 10. Synthesis of target molecular hybrid 3 . 
simultaneously in one hybrid (structures shown in SI section). However, we faced problems with the solubility of key intermediates (i.e., the disubstituted triazine with morpholine and naphthoquinone or quinoline group), which could drive the desired hybrid. Even using the one pot methodology in which the nucleophiles were added at different temperatures $\left(0^{\circ} \mathrm{C}\right.$, room temperature and reflux $)$, the hybrid could not be obtained.

\section{Anticancer activity}

Malignant melanoma is the most aggressive form of skin cancer. Most patients are diagnosed in early stages when the disease is curable. However, the more advanced or metastatic cases have always been a challenge for physicians. The poor prognosis for patients with melanoma has been changing since numerous of promising therapeutic protocols have appeared recently. ${ }^{48}$ Nevertheless, the development of new possible methods of treatment is still needed with improved durable response rates and wider target populations to treat metastatic melanoma.

In this study, we show that it is possible to decrease the viability of the metastatic melanoma cell line as well as the activity and expression of AMPK and PI3K kinases, both of which positively modulate the autophagy process. Autophagy is stimulated in response to both physiological and pathological conditions such as starvation, hypoxia and low energy as well as protein aggregates. This process is a crucial adaptive response that initiates the sequestration of damaged or ageing intracellular content and leads to its degradation. This is a well-organized process that ensures important quality control of the cytoplasmic components along with the generation of building blocks to support cell proliferation and survival. . 3,54

This multistep catabolic process has been shown to play an especially important role in melanoma acquisition of resistance to anti-cancer therapies. ${ }^{53}$ Therefore, the aberrant control of autophagy has been considered among key hallmarks of cancer, including melanoma. ${ }^{55,56}$

Intermediate $\mathbf{1 0}$ and molecular hybrids $\mathbf{2}$ and $\mathbf{3}$, which display the 1,3,5-triazinic and morpholine core, decreased the viability of SKMEL-103 (N-RAS mutated) with $\mathrm{IC}_{50}$ values around $25 \mu \mathrm{M}$. Temozolomide was used as the control drug. The other compounds tested $\mathbf{1 , 9}$ and $\mathbf{1 1}$ did not obtain relevant cytotoxicity. These results point clearly to the synergism between triazine, morpholine and quinoline to compound $\mathbf{2}$ or naphthoquinone to $\mathbf{3}$. However, morpholine and triazine appear to be essential for cytotoxic activity, since intermediate 11, which does not have the naphthoquinone and quinolinic portion, also showed increased cytotoxicity in the cancer studied. The interaction energy obtained in the docking studies corroborate with the experimental data where the compound $\mathbf{3}$ was the most effective.

Interestingly, the molecular hybrids $\mathbf{2}$ and $\mathbf{3}$ and intermediate $\mathbf{1 0}$ negatively modulate both signaling ways, PI3K and AMPK, in the melanoma SKMEL-103 cells. Expressions of PI3K and AMPK were determined using western blotting and equal loading was confirmed by reprobing blots for tubulin. Figure 11 summarizes the relevant results of melanoma cells viability expressions of PI3K and AMPK.

(A) Melanoma cells viability

(a)

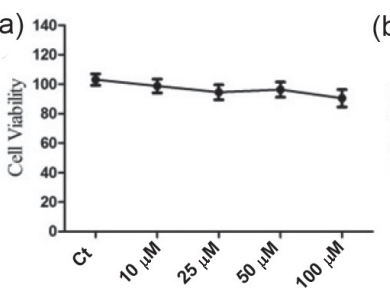

(c)

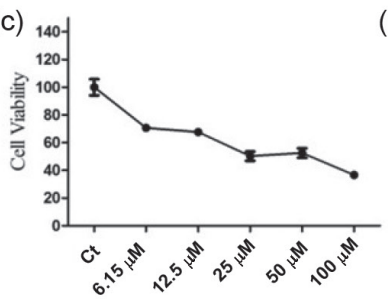

(b) 140

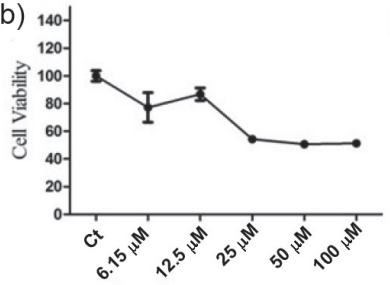

(d)

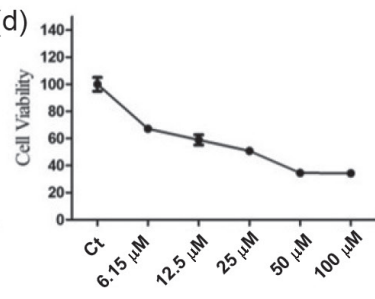

(B) Expression of PI3K and AMPK

(a)
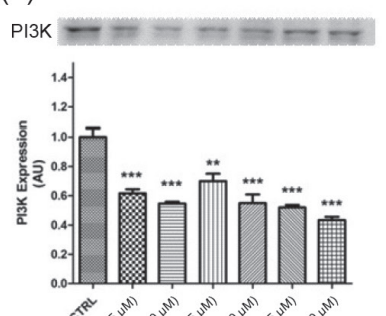

की

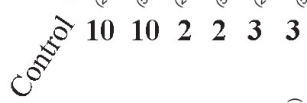

(c)

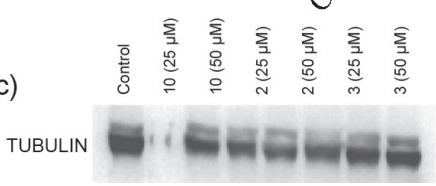

(b) рАMPK $=-\square=-$
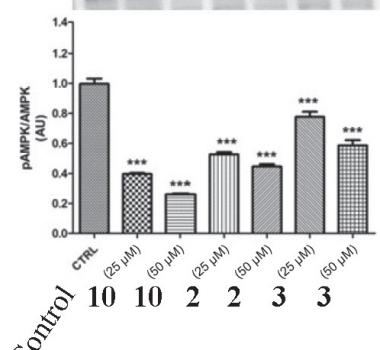

Figure 11. (A) Results of (a) temozolomide; (b) intermediate 10; (c) and (d) molecular hybrids $\mathbf{2}$ and $\mathbf{3}$, respectively, on melanoma cells viability (SKMEL-103). SKMEL-103 cells were treated with the compounds for $24 \mathrm{~h}$. Cell viability was measured by MTT assay and cell viability of non-treated cells was considered as $100 \%$. Data are shown as mean \pm SEM $(\mathrm{n}=6)$. $* * p<0.01$, ***p $p<0.001 v s$. control and n.s.: not significant, assessed with ANOVA followed by a Tukey's test. (B) Results of intermediate $\mathbf{1 0}$ and molecular hybrids $\mathbf{2}$ and $\mathbf{3}$ downregulating (a) PI3K and (b) AMPK. Expressions of PI3K and AMPK in SKMEL-103 cells were determined using western blotting. Equal loading was confirmed by reprobing blots for tubulin (c). 


\section{Conclusions}

Molecular hybridization was accomplished by gathering together four structures (morpholine, naphthoquinone, quinolone and 1,3,5-triazine) with renowned anticancer activity in three novel substances. We started our work with a rational design of potential drugs, investigating interaction energies between the hybrids with PI3K $\gamma$ and AMPK enzymes by docking studies. From this, the synergism of the triazine, morpholine and naphthoquinone moieties was clearly observed by the greater bind affinity of the complex formed between hybrid 3 and biological receptor tested. For PI $3 \mathrm{~K} \gamma$, the interactions are commonly electrostatic, mainly with the amino acid residues Lys833 and Lys807 in its active site. For AMPK, the main observed interactions were hydrogen bonds with Ser314 and Ser226 amino acid residues that also appeared in complex ligand / enzyme of the control drugs. The preliminary positive results from docking encouraged us to synthesize the novel molecular hybrids $\mathbf{1}, \mathbf{2}$ and $\mathbf{3}$, which were obtained in yields ranging from 43 to $84 \%$ in three steps. Biological results showed that compounds $\mathbf{2}, \mathbf{3}$ and intermediate $\mathbf{1 0}$ decreased the viability of melanoma cells and negatively modulated the expression of PI3K, inhibiting AMPK as well. As predicted by docking, the in vitro tests also showed that compound 3 was the most cytotoxic in SKMEL-103 cells evidencing the synergism of naphthoquinone associated with morpholine and triazine cores.

\section{Supplementary Information}

Supplementary information is available free of charge at http://jbcs.sbq.org.br as PDF file.

\section{Acknowledgments}

Authors acknowledge the Conselho Nacional de Desenvolvimento Científico e Tecnológico (CNPq 449984/2014-1 and 305117/2017-3), the Coordenadoria de Aperfeiçoamento de Pessoal do Nível Superior (CAPES), Fundação de Amparo à Pesquisa do Espírito Santo (FAPES) and Fundação de Amparo à Pesquisa de Minas Gerais (FAPEMIG APQ-00557-14 and APQ-02742-17) for their financial support.

\section{References}

1. World Health Organization (WHO); Cancer Fact Sheet, 2018, available at https://www.who.int/cancer/PRGlobocanFinal.pdf, accessed in May 2019.
2. Mishra, S. S.; Singh P.; Eur. J. Med. Chem. 2016, 124, 500.

3. Raj, R.; Land, K. M.; Kumar, V.; RSC Adv. 2015, 5, 82676; Muregi, W.; Ishih, A.; Drug Dev. Res. 2010, 71, 20; Rana, A.; Alex, J. M.; Chauhan, M.; Joshi, G.; Kumar, R.; Med. Chem. Res. 2015, 24, 903.

4. Nepali, K.; Sharma, S.; Sharma, M.; Bedi, P. M. S.; Dhar, K. L.; Eur. J. Med. Chem. 2014, 77, 422.

5. Eccleston, A.; Dhand, R.; Nature 2006, 441, 423.

6. Asati, V.; Debarshi, M. K.; Bharti, S. K.; Eur. J. Med. Chem. 2016, 109, 314.

7. Hanahan, D.; Weinberg, R. A.; Cell 2000, 100, 57.

8. Plenchette, S.; Romagny, S.; Laurens, V.; Bettaieb, A.; Redox Biol. 2015, 6, 507.

9. Vivanco, I.; Sawyers, C. L.; Nat. Rev. Cancer 2002, 2, 489.

10. Coskun, D.; Obakan, P.; Arisan, E. D.; Çoker-Gürkan, A.; Palavan-Ünsal, N.; Exp. Cell Res. 2015, 338, 10.

11. Engelman, J. A.; Nat. Rev. Cancer 2009, 9, 550.

12. Wong, K. K.; Engelman, J. A.; Cantley, L. C.; Curr. Opin. Genet. Dev. 2010, 20, 87.

13. Bunney, T. D.; Katan, M.; Nat. Rev. Cancer 2010, 10, 342.

14. Woodard, J.; Platanias, L. C.; Biochem. Biophys. Res. Commun. 2010, 398, 135.

15. Madhunapantula, S. V.; Robertson, G. P.; Enzyme Res. 2011, 2011,20

16. Gonçalves, P. R.; Rocha-Brito, K. J.; Fernandes, M. R.; Abrantes, J. L.; Durán, N.; Ferreira-Halder, C. V.; Tumor Biol. 2016, 37, 14049.

17. Checinska, A.; Soengas, M. S.; Pigm. Cell Melanoma Res. 2011, 24, 1116

18. Kennedy, S.; DiCesare, J. C.; Sheaff, R. J.; Biochem. Biophys. Res. Commun. 2011, 410, 152.

19. Boonyalai, N.; Sittikul, P.; Pradidphol, N.; Kongkathip, N.; Biomed. Pharmacother. 2013, 67, 122.

20. Tandon, V. K.; Kumar, S.; Expert Opin. Ther. Pat. 2012, 23, 2094.

21. Kim, T.-J.; Yun, Y.-P.; Vasc. Pharmacol. 2007, 46, 31.

22. Liu, Q.; Wang, J.; Kang, S. A.; Thoreen, C. C.; Hur, W.; Ahmed, T.; Sabatini, D. M.; Gray, N. S.; J. Med. Chem. 2011, 54,1473

23. Boldt, S.; Kolch, W.; Curr. Pharm. Des. 2004, 10, 1885.

24. Li, S.; Guo, C.; Sun, X.; Li, Y.; Zhao, H.; Zhan, D.; Lan, M.; Tang, Y.; Eur. J. Med. Chem. 2012, 49, 271.

25. Shahabuddin, M. S.; Gopal, M.; Raghavan, C. S.; J. Photochem. Photobiol., B 2009, 94, 13.

26. Xia, Y.; Yang, Z. Y.; Hackl, T.; Hamel, E.; Mauger, A.; Wu, J. H.; Lee, K. H.; J. Med. Chem. 2001, 44, 3932.

27. Thapa, P.; Karki, R.; Yoo, H. Y.; Park, P. H.; Lee, E.; Jeon, K. H.; Na, Y.; Cho, W.; Bioorg. Chem. 2012, 40, 67.

28. Caprio, V.; Guyen, B.; Boahen, Y. O.; Mann, J.; Gowan, S. M.; Kelland, L. M.; Read, M. A.; Needle, S.; Bioorg. Med. Chem. Lett. 2000, 11, 2063. 
29. Wurz, R. P.; Liu, L.; Yang, K.; Nishimura, N.; Bo, Y.; Pettus, L. H.; Caenepeel, S.; Freeman, D. J.; McCarter, J. D.; Mullady, E. L.; San Miguel, T.; Wang, L.; Zhang, N.; Andrews, K. L.; Whittington, D. A.; Jiang, J.; Subramanian, R.; Hughes, P. E.; Normam, M. H.; Bioorg. Med. Chem. Lett. 2012, 22, 5714.

30. Pogorelčnik, B.; Brvar, M.; Zajc, I.; Filipičb, M.; Solmajer, T.; Perdih, A.; Bioorg. Med. Chem. Lett. 2014, 24, 5762.

31. Liu, B.; Sun, T.; Zhou, Z.; Du, L.; Med. Chem. 2015, 5, 131.

32. Al-Ghorbani, M.; Vigneshwaran, V.; Ranganatha, L.; Prabhakar, B. T.; Ara Khanun, S.; Bioorg. Chem. 2015, 60, 136.

33. Ibrahim, M. A.; Abou-Seri, S. M.; Hanna, M. M.; Abdalla, M. M.; El Sayed, N A.; Eur. J. Med. Chem. 2015, 99, 1.

34. Rewcastle, G. W.; Gamage, S. A.; Flanagan, J. U.; Kendall, J. D.; Denny, W. A.; Baguley, B. C.; Buchanan, C. M.; Chao, M.; Kestell, P.; Kolekar, S.; Lee, W.-J.; Lill, C. L.; Malik, A.; Singh, R.; Jamieson, S. M. F.; Shepherd, P. R.; Eur. J. Med. Chem. 2013, 64, 137.

35. Venkatesan, A. M.; Chen, Z.; dos Santos, O.; Dehnhardt, C.; Delos Santos, E.; Ayral-Kaloustian, S.; Mallon, R.; Hollander, I.; Feldberg, L.; Lucas, J.; Yu, K.; Chaudhary, I.; Mansour, T. S.; Bioorg. Med. Chem. Lett. 2010, 20, 5869.

36. Yrjölä, S.; Sarparanta, M.; Airaksinen, A. J.; Hytti, M.; Kauppinen, A.; Pasonen-Seppänen, S.; Adinolfi, B.; Nieri, P.; Manera, C.; Keinänen, O.; Poso, A.; Nevalainen, T. J.; Parkkari, T.; Eur. J. Pharm. Sci. 2015, 67, 85.

37. Meng, X.-Y.; Zhang, H.-X.; Mezei, M.; Cui, M.; Curr. Comput. Aided Drug Des. 2011, 7, 146.

38. Ruyck, J.; Brysbaert, G.; Blossey, R.; Lensink, M. F.; Adv. Appl. Bioinf. Chem. 2016, 9, 1.

39. Ranjbar, S.; Edraki, N.; Khoshneviszadeh, M.; Foroumadi, A.; Miri, R.; Khoshneviszadeh, M.; Res. Pharm. Sci. 2018, 13, 1.

40. Zhao, B.; Lei, F.; Wang, C.; Zhang, B.; Yang, Z.; Li, W.; Zhu, W.; $\mathrm{Xu}, \mathrm{S}$.; Molecules 2018, 23, 553.

41. Borgati, T. F.; Nascimento, M. F. A.; Bernardino, J. F.; Martins, L. C. O.; Taranto, A. G.; Oliveira, A. B.; J. Trop. Med. 2017, 7496934.

42. Walker, E. H.; Pacold, M. E.; Perisic, O.; Stephens, L.; Hawkins, P. T.; Whymann, M. P.; Williams, R. L.; Mol. Cell. 2000, 6, 99; McNamara, C. R.; Degteev, A.; Future Med. Chem. 2011, 3, 549.
43. Day, P.; Sharff, A.; Parra, L.; Cleasby, A.; Williams, M.; Horer, S.; Nar, H.; Redemann, N.; Tickle, I.; Yon, J.; Acta Crystallogr., Sect. D: Struct. Biol. 2007, 63, 587.

44. Trott, O. E.; Olson, A.; J. Comput. Chem. 2010, 31, 455.

45. Brozell, S. R.; Mukherjee, S.; Balius, T. E.; Roe, D. R.; Case, D. A.; Rizzo, R. C.; J. Comput.-Aided Mol. Des. 2012, 26, 749; Yuriev, E.; Ramsland, P. A.; J. Mol. Recognit. 2013, 26, 215.

46. Petti, C.; Vegetti, C.; Molla, A.; Bersani, I.; Cleris, L.; Mustard, K. J.; Formelli, F.; Hardie, G. D.; Sensi, M.; Anichini, A.; Melanoma Res. 2012, 22, 341.

47. Chen, L.; Chen, Q.; Deng, G.; Kuang, S.; Lian, J.; Biochem. Biophys. Res. Commun. 2016, 480, 515.

48. Carmo, A. M. L.; Silva, F. M. C.; Machado, P. A.; Fontes, A. P. S.; Pavan, F. R.; Leite, C. Q. F.; Leite, S. R. A.; Coimbra, E. S.; da Silva, A. D.; Biomed. Pharmacother. 2011, 65, 204.

49. Delarmelina, M.; Daltoé, R. D.; Cerri, M. F.; Madeira, K. P.; Rangel, L. B. A.; Lacerda Jr., V.; Romão, W.; Taranto, A. G.; Greco, S. J.; J. Braz. Chem. Soc. 2015, 26, 1804.

50. Delarmelina M.; Greco, S. J.; Carneiro, J. W. M.; Tetrahedron 2017, 73, 4363.

51. Venkatesan, A. M.; Dehnhardt, C. M.; Santos, E. D.; Chen, Z.; dos Santos, O.; Ayral-Kaloustian, S.; Khafizova, G.; Brooijmans, N.; Mallon Robert; Hollander, I.; Feldberg, L.; Lucas, J.; Yu, Ker.; Gibbons, J.; Abraham, R. T.; Chaudhary, I.; Mansour, T. S.; J. Med. Chem. 2010, 53, 2636.

52. Blotny, G.; Tetrahedron 2006, 62, 9507.

53. Klionsky, D. J. et al.; Autophagy 2016, 12, 1.

54. Amaravadi, R. K.; Thompson, C. B.; Clin. Cancer Res. 2007, 13, 7271 .

55. Checinska, A.; Soengas, M. S.; Pigm. Cell Melanoma Res. 2011, 24, 1116.

56. Corazzari, M.; Fimia, G. M.; Lovat, P.; Piacentini, M.; Semin. Cancer Biol. 2013, 23, 337.

Submitted: February 18, 2019 Published online: May 16, 2019 